Editorial

\title{
The Turn to Affect and Emotion in Media Studies
}

\author{
Margreth Lünenborg * and Tanja Maier \\ Institute for Media and Communication Studies, Freie Universität Berlin, 14159 Berlin, Germany; \\ E-Mails: margreth.luenenborg@fu-berlin.de (M.L), tanja.maier@fu-berlin.de (T.M.) \\ * Corresponding author
}

Submitted: 3 September 2017 | Published: 11 September 2018

\begin{abstract}
This editorial delivers an introduction to the thematic Media and Communication issue on "The Turn to Affect and Emotion in Media Studies". The social and cultural formation of affect and emotion has been of central interest to social science-based emotion research as well as to affect studies, which are mainly grounded in cultural studies. Media and communication scholars, in turn, have especially focused on how emotion and affect are produced by media, the way they are communicated through media, and the forms of emotion audiences develop during the use of media. Distinguishing theoretical lines of emotion theory in social sciences and diverse traditions of affect theory, we reflect on the need to engage more deeply with affect and emotion as driving forces in contemporary media and society. This thematic issue aims to add to ongoing affect studies research and to existing emotion research within media studies. A special emphasis will be placed on exploring structures of difference and power produced in and by media in relation to affect and emotion.
\end{abstract}

\section{Keywords}

affect; body emotion; communication; media studies; power

\section{Issue}

This editorial is part of the issue "The Turn to Affect and Emotion in Media Studies", edited by Margreth Lünenborg and Tanja Maier (Free University Berlin, Germany).

(C) 2018 by the authors; licensee Cogitatio (Lisbon, Portugal). This article is licensed under a Creative Commons Attribution 4.0 International License (CC BY).

\section{Theoretical Background(s)}

The social and cultural formation of affect and emotion has been of central interest to social science-based emotion research as well as to affect studies, which are mainly grounded in cultural studies. The study of emotion and affect has received increasing attention since the shift to affect studies in the 1990s focusing bodies and materiality again. Under the umbrella of affect theory (Gregg \& Seigworth, 2010), an ensemble of theoretical approaches has emerged in diverse areas, providing new insights into the shaping of social relationships and inequalities. The often-used term "affective turn" (Clough \& Halley, 2007) may suggest coherent understanding where, in reality, diverse and thoroughly different conceptions and approaches exist. In examining the notion of a "turn to affect and emotion in media studies", we aim to reflect on the intensified preoccupation with affect and emotion and on new approaches in media research. Media can be understood as "affect generators" (Reckwitz, 2017) and as institutions establishing "feeling rules" (Hochschild, 1979). Current phenomena like hate speech and "shitstorms" via social media are to be understood as explicit public articulations of emotions; at the same time, they produce affective dynamics, which can be described as contagious and viral. Obviously, emotions are used in public communication to gain attention, be it in journalism, advertising, or public diplomacy. Digital communication, in its temporal dynamics and intensities, can especially be understood with regard to "affective flows" (Wetherell, 2012; adapted to social media analysis most recently by Sampson, Maddison, \& Ellis, 2018). This thematic issue, beyond offering mere descriptions of these phenomena, is concerned with advancing 
the debate on the potentials of different theoretical approaches to analyze affect and emotion as driving forces in contemporary societies and media cultures.

There are no universally shared definitions of the terms "affect" and "emotion" in the fields of social and cultural research. Affect is often described as something that hits and captures us, that moves us and connects us with other bodies (e.g., Clough, 2010). While affect and emotion are often considered synonymous, there have been theoretical efforts to distinguish between them. In such frameworks, affect is described as intensity (Massumi, 2002) or a dynamic, relational occurrence through which bodies are connected to each other (e.g., RöttgerRössler \& Slaby, 2018), while emotion is understood as a complex, socially formed interplay of thoughts and feelings, as outlined over 30 years ago by Hochschild (1983). Critics argue that distinctions between affect and emotion are untenable. At any rate, these questions and disagreements, as well as the conceptual openness and complexity of affect, pose theoretical, analytical and methodological challenges to the studies of media and communication. Therefore, theoretical development, methodological designs and definitions of terms will have to be closely interlinked to increase a consistent body of knowledge.

Before introducing contributions to this thematic issue, we will give a brief overview of the most relevant theoretical approaches to affect and emotion research in media and communication studies. We have classified these theoretical frameworks into distinct categories. Due to the field's complexity and tremendous productivity within recent years, this cannot be comprehensive at all, but the approaches we introduce will be discussed in each of this issue's articles. As social theories, all these approaches go far beyond a mere understanding of media and communication, exploring the ways affect and emotion contribute to social formations, sense of belonging and constitution of identities.

Psychoanalytical approaches are especially established in film studies and gender media analysis. The theoretical inspiration for this approach comes predominantly from the work of Sigmund Freud and Jacques Lacan. Psychoanalytical conceptions of affect explain viewers' affects and emotions by means of unconscious psychosexual processes, which influence visual pleasure on a physical level (Stadler, 2014). Some authors of affect studies now reject psychoanalytic theories, ascribing the unconscious parts of affective relationships to media and environment (e.g., Angerer, 2014).

When studied as a connection between media psychology and neuroscience, affect is mostly defined as an arousal wherein cognitive and physical aspects interact. This perspective shows the kinship of the affective turn concept with biological thinking, following authors like Charles Darwin and Paul Ekman (Seigworth \& Gregg, 2010). Psychological expression research, with its understanding of the physical visibility of basic emotions, is relevant to this model; for example in the field of visual stud- ies, which examines the globalized visual language of affect (e.g., Angel \& Gibbs, 2006). This approach considers affect and media on a biological as well as socio-cultural level, often questioning the relationship between culture and nature.

In contrast, critical approaches through the lens of cultural (media) studies are based on a fundamentally socially and culturally grounded understanding of affect and emotion (for an overview, see Harding \& Pribram, 2009). The current debates in affect studies are shaped by Williams' "structures of feelings" (1977/2015) concept, which describes the relationship of institutional order as structural limitation with emergent forms of social and cultural interaction as lived practice. Subsequently, other studies have investigated specific phenomena, like reality TV, as "technology of intimacy" (Kavka, 2008). This conceptual approach pursues an understanding of affect that seeks to capture circulation, relation and transformation between spectators, media texts and media production. These concepts are closely connected to more philosophical works on affect.

Philosophical approaches have focused on affect as intensity and process (e.g., Seigworth \& Gregg, 2010). The work of philosophers Gilles Deleuze (reflecting on Baruch Spinoza) and Brian Massumi seem to be at the forefront of efforts defining the term. This perspective on affect often focuses on (media) technologies (e.g., Coole \& Frost, 2010) as significant elements of contemporary human and non-human relationship, and as forms of new materialism (e.g., Angerer, 2017). Such approaches have become popular in philosophical and ontological research on technology and (digital) media studies regarding the independence and unavailability of affect.

Partly following from that, social-relational approaches focus on situationally bound, relationally affective occurrences in contemporary societies. Such approaches are represented by the interdisciplinary "Affective Societies" Collaborative Research Center at Freie Universität Berlin (http://www.sfb-affectivesocieties.de/en), of which the editors of this thematic issue are part of, also, e.g., Röttger-Rössler and Slaby (2018). This institution proposes a new way of thinking about social, technical and cultural processes of mediation and the interferences of affect (e.g., Blackman, 2018; Lünenborg, Maier, \& Töpper, in press), providing scholars with a framework focusing on the relational character of affect in contemporary media cultures.

On balance, the overall impression is that affect studies-based approaches can potentially overcome existing dichotomies between culture and nature, between cognition and emotion, between inside and outside, and between the psychological and the social. Here it must be asked how these theoretical concepts can be made productive for future media and communication studies, and moreover, how different approaches with disparate theoretical presuppositions may be integrated. The articles in this thematic issue address these questions in different ways. 


\section{Contributions}

Brigitte Hipfl (2018) opens the thematic issue with the article "Affect in media and communication studies: Potentials and assemblages". Her essay follows traditions of cultural studies and philosophical affect research. Hipfl presents a convincing contribution, discussing what a Deleuze-Guattarian approach to affect can offer to the field of media and communication studies.

Bernd Bösel's (2018) article "Affect disposition(ing): A genealogical approach to the organization and regulation of emotions" provides valuable new insights to the field of digitization and the humanities. Relying on philosophical concepts of affect theory, the author takes a critical and genealogical look at affective technologies like affective computing and social media, then shifts to an exploration of how technologies are used to detect and induce affects in human bodies.

In his contribution "Towards a psychoanalytic concept of affective-digital labour", Jacob Johanssen (2018) starts from the concept of affective work posited by Hardt and Negri, arguing that the Freudian model of affect can contribute to existing philosophical concepts. In doing so, Johannsen turns attention to the unconscious nature of affective work on social media, taking discursive and physical aspects of experience into account.

Laura Sūna (2018) offers an empirical contribution to media-related affect studies with her article "Negotiating belonging as cultural proximity in the process of adapting global reality TV formats". The author draws on approaches from cultural studies, combining them with a social concept of emotion. In interviewing media producers, she focuses on reality TV as a globally marketed television format, revealing modes of mediated belonging that are understood as forms of organized sociality through affective practices.

Yuanchen Zhang (2018) also deals with questions concerning the cultural role of emotions within global reality TV formats. Her article "How culture influences emotion display in transnational television formats: The case of The Voice of China" draws on Ekman's concept of anthropologically universal articulations of emotion. With this framework, Zhang analyzes the global TV format The Voice and discusses the presence of universal and culturally specific emotions in its Chinese adaptation.

In the final article, "Leak early, leak (more than) often: Outlining the affective politics of data leaks in network ecologies", Alberto Micali (2018) uses a local case study: the 2012 data leak carried out by Anonymous Italiana. The author relies on philosophical affect theories to present his argument that contemporary digital data leaking in a networked world can be understood as a form of affective politics.

To sum up, the articles of this thematic issue present empirical, analytical and theoretical investigations, reflecting the importance of affect and/or emotion in research on media and communication. They provide possibilities for further reflections on the significance of affec- tive dynamics within current media-saturated societies. This thematic issue of Media and Communication deals with different theoretical concepts of affect and emotion in various media, genres and formats, as well as with media as technological artifact. We hope the contributions provide fresh insights into the politics and intertwining of affect, emotion, belonging and power in media and communication studies.

\section{Acknowledgements}

The articles of this thematic issue are based on papers presented at the international "Affects-Media-Power" conference held at Freie Universität Berlin in 2017. This conference was organized by Project B02 ("Transcultural Emotional Repertoires in and through Reality TV") within the "Affective Societies" Collaborative Research Center (CRC 1171) of Freie Universität Berlin and the German Association of Communication Research (DGPuK) "Sociology of Media and Communication" division (in cooperation with the "Media, Gender and Public Sphere" division). We would like to thank Sigrid Kannengießer, Marian Adolf and Claudia Töpper for organizing the conference with us, as well as all the authors, the numerous reviewers, and Rodrigo Gomes and Cátia Simões from the journal's editorial office for their valuable contributions to this issue.

\section{References}

Angel, M., \& Gibbs, A. (2006). Media, affect and the face: biomediation and the political scene. Southern Review: Communication, Politics and Culture, 38(2), 24-39.

Angerer, M.-L. (2014). Desire after affect. Lanham, MD: Rowman \& Littlefield.

Angerer, M.-L. (2017). Ecology of affect. Intensive milieus and contingent encounters. Lüneburg: Meson Press. Retrieved from https://meson.press/books/ecologyof-affect

Blackman, L. (2018). Affect and mediation. In B. RöttgerRössler, \& J. Slaby (Eds.), Affect in relation: families, places, technologies. Essays on affectivity and subject formation in the 21st century (pp. 221-240). New York, NY: Routledge.

Bösel, B. (2018). Affect disposition(ing): A genealogical approach to the organization and regulation of emotions. Media and Communication, 6(3), 15-21.

Clough, P. T. (2010). The affective turn. Political economy, biomedia, and bodies. In M. Gregg, \& G. J. Seighworth (Eds.), The affect theory reader (pp. 206-225). Durham and London: Duke University Press.

Clough, P. T., \& Halley, J. (2007). The affective turn: Theorizing the social. Durham and London: Duke University Press.

Coole, D. H., \& Frost, S. (Eds.). (2010). New materialisms: Ontology, agency, and politics. Durham and London: Duke University Press. 
Gregg, M., \& Seigworth G. J. (2010). The affect theory reader. Durham: Duke University Press.

Harding, J., \& Pribram, E. D. (Eds.). (2009). Emotions: A cultural studies reader. Abingdon and New York: Routledge.

Hipfl, B. (2018). Affect in media and communication studies: Potentials and assemblages. Media and Communication, 6(3), 5-14.

Hochschild, A. R. (1979). Emotion work, feeling rules, and social structure. American Journal of Sociology, 85(3), 551-575.

Hochschild, A. R. (1983). Managed heart: Commercialization of human feeling. Berkeley, CA: University of California Press.

Johanssen, J. (2018). Towards a psychoanalytic concept of affective-digital labour. Media and Communication, 6(3), 22-29.

Kavka, M. (2008). Reality television, affect and intimacy: Reality matters. Houndmills and New York: Palgrave.

Lünenborg, M., Maier, T., \& Töpper, C. (in press). Affekte als sozial-relationales phänomen medialer kommunikation. Affekttheorien für die medienforschung nutzbar machen [Affects as social-relational phenomenon of media communication-The adaption of affect theories in media research]. Studies in Communication and Media.

Massumi, B. (2002). Parables for the virtual: Movement, affect, sensation. Durham, NC: Duke University Press.

Micali, A. (2018). Leak early, leak (more than) often: Outlining the affective politics of data leaks in network ecologies. Media and Communication, 6(3), 48-59.

Reckwitz, A. (2017). Practices and their affects. In A. Hui, T. Schatzki, \& E. Shove (Eds.), The nexus of practices (pp. 114-125). Abingdon: Routledge.

Röttger-Rössler, B., \& Slaby, J. (Eds.). (2018). Affect in relation: Families, places, technologies. Essays on affectivity and subject formation in the 21st century. New York, NY: Routledge.

Sampson, T., Maddison, S., \& Ellis, D. (2018). Affect and social media. Emotion, mediation, anxiety and contagion. London: Rowman \& Littlefield.

Seigworth, G. J., \& Gregg, M. (2010). An inventory of shimmers. In M. Gregg \& G. J. Seigworth (Eds.), The affect theory reader (pp. 1-25). Durham: Duke University Press.

Stadler, J. (2014). Affect, film and. In E. Branigan \& W. Buckland (Eds.), The Routledge encyclopedia of film theory (pp. 1-6). Abingdon: Routledge.

Sūna, L. (2018). Negotiating belonging as cultural proximity in the process of adapting global reality TV formats. Media and Communication, 6(3), 30-39.

Tuschling, A. (2013). Gesichter der Werbung, Gesichter der Wissenschaft [Faces of advertising, faces of science]. ZFM Zeitschrift für Medienwissenschaft, 9, pp. 31-42.

Wetherell, M. (2012). Affect and emotion. A new social science understanding. London: Sage.

Williams, R. (2015). Structures of feeling. In D. Sharma \& F. Tygstrup (Eds.), Structures of feeling. affectivity and the study of culture (pp. 20-26). Berlin: De Gruyter. (Original work published 1977)

Zhang, Y. (2018). How culture influences emotion display in transnational television formats: The case of "The Voice of China". Media and Communication, 6(3), 40-47.

\section{About the Authors}
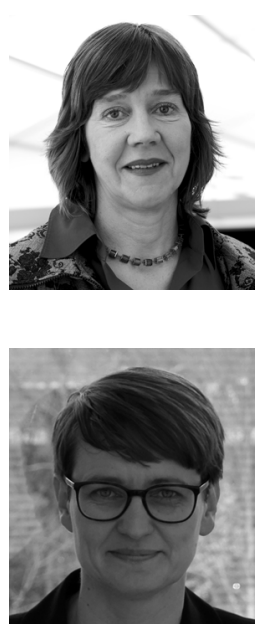

Margreth Lünenborg is Professor of Media and Communication studies at Freie Universität Berlin. Her research focuses in the field of Journalism Studies, Gender Media Studies, Media and Migration. As a PI in the collaborative research center "Affective Societies" she is currently working on affects and emotion in media communication.

Tanja Maier is a Senior Lecturer for Media and Communication studies and currently working as an associated member at the collaborative research center "Affective Societies" at Freie Universität Berlin. Her research interests include Visual Communication and Culture, Cultural Studies and Digital Media, Affect Studies and Transcultural Communication, Gender Media Studies. 